\title{
Why the Territorial Dispute between Japan and China cannot be Resolved
}

Hiroshi Saito

Faculty of Law, Toyo University

Follow this and additional works at: https://gensoken.toyo.ac.jp/japanese-society-and-culture

Part of the Chinese Studies Commons, International Law Commons, and the Japanese Studies Commons

\section{Recommended Citation}

Saito, Hiroshi (2020) "Why the Territorial Dispute between Japan and China cannot be Resolved," Japanese Society and Culture: Vol. 2 , Article 5.

DOI: 10.52882/2434-1738-0205

Available at: https://gensoken.toyo.ac.jp/japanese-society-and-culture/vol2/iss1/5

This Research Note is brought to you for free and open access by Institute of Social Sciences. It has been accepted for inclusion in Japanese Society and Culture by an authorized editor of Institute of Social Sciences. 


\title{
Why the Territorial Dispute between Japan and China cannot be Resolved*
}

\author{
Hiroshi Saito $*$
}

\begin{abstract}
This essay aims to suggest that the different idea of war would be a legal ground of each one on the territorial dispute between two States. There are three deferent time stages for the idea about war. The first stage is "the present time" which the developed states including Japan belong to and armed forces cannot be used to resolve international problems. The second is" the past time" especially time before the World War Two in which some developing states including China use armed forces to international conflicts. The third is "the ancient time" in which dictatorial or collapsed states exist and cannot be understood their principle of conducts. Then, Japan and China et al have deferent principle of conducts based on the deferent time stages, that is one of the fundamental reasons not to resolve territorial issues.
\end{abstract}

Key words: Japan, China, Territory, Time, War

1. I thank you for according me the opportunity to present this report on the territorial dispute that persists between Japan and China with regard to the Senkaku Islands. This issue has negatively influenced relations between the two states.

Given the theme of the conference, I wanted initially to present a report on a legal topic related to Italy and Japan. However, I later thought it would be more useful and interesting to present the East Asian situation from the point of view of international law. The opinions I will express during this presentation are not endorsed by the Japanese institution to which I belong; they are my personal views.

2. The territorial dispute between Japan and China with regard to the Senkaku Islands is still unresolved. The story has remained unsettled for about half a century. So, far, scholars or journalists discussed the issue on the basis of interpretations of historical facts ascertained through a partial perspective of the full picture. Thus, China has not accepted the mandatory jurisdiction of the International Court of Justice (ICJ) and contends that the matter cannot be submitted to the ICJ. The United States of America, a country that exerts great influence in the region, has left the resolution of the dispute to the two concerned nations.

Why was it not possible to resolve this controversy for almost half a century? Generally, to resolve an issue, the facts must first be clarified. However, I believe that this task poses a fundamental problem in East Asia, especially with regard to relations between Japan and China. Due to the time limits, I would

\footnotetext{
※ This manuscript is translated version of the existing report "Perché non si può risolvere la controversia territoriale tra Giappone e Cina?" written by the same author. This was prepared for the report delivered at the convention of the Italian-Japanese Association for Comparative Law on 26 November 2014 at the Palazzo Coppini, Sala Komech in Florence.

※ Professor, Faculty of Law, Toyo University, International Law and Philosophy of Jurisprudence. Visiting Researcher of Istituto Giuridico Antonio Cicu, University of Bologna (2009).
} 
like to restrict my presentation today to a specific and crucial aspect from the perspective of international law.

3. When two parties intend to resolve a problem by taking recourse to legal provisions, they must share a principle, or an idea, that orders society: the notion of right and wrong. The identification and subsequent application of the law or the principles of customary law that are applicable to a dispute can help in the resolution of the conflict only when two parties are fundamentally aligned in terms of the grounding of the legality of an issue. Problems of interpreting the law in the abstract may still occur in such instances of fundamental congruence, and parties can then research, discover, rethink and discuss doctrines and precedents.

However, this approach cannot be used in the case of the Senkaku Islands. It is my belief that the fundamental problem of alignment to legal principles has remained unsolved in this instance. The essential and unanswered aspect pertains to the problem of defining the notion of war, and in particular, the determination of whether or not a war is lawful. This problem is both ancient and critical.

4. In short, Japan and China cannot find a common legal framework that can be made applicable to the problem of the Senkaku Islands. This inability of consensus occurs, in my view, due to a very basic disagreement about the notion of war. The dispute is, in fact, applicable to the Second World War as two opposite opinions exist on the legality of World War II.

China claims that the Senkaku Islands belong to China according to international law because these Islands originally belonged to the Qing dynasty [Ch'ing] to which modern China corresponds. According to China, Japan occupied this region through military force before the Second World War. However, it was believed at that time that war was illegal; thus the Japanese action was unlawful and should be revoked.

In opposition, Japan claims that the Senkaku Islands did not belong to China and that they were peacefully included within the borders of Japan. According to Japan, no one objected to its actions relating to the Islands until the 1970s, when hydrocarbon deposits were discovered in the Senkaku area. At that time, the Islands were already under the purview of Japanese sovereignty as per international customary law ${ }^{1}$.

When research is conducted on these two positions, it is understood that the application of the law is underpinned by differing notions about war and that there exist controversial issues of international politics involving the United States of America.

5. First, the idea of war in international law must be elucidated. China's opinions coincide with the stated position of the United States. China claims that war was already considered illegal before the outbreak of the Second World War. On the contrary, Japan opines that the idea of the lawlessness of war was mooted in Asia at the time of the so-called 'Tokyo Trial,' and that the Japanese action pertaining to the Senkaku Islands occurred before the Second World War and was not illegal since that action was legal according to the international law that prevailed at that time.

1 Ministry of Foreign Affairs of Japan, < https://www.mofa.go.jp/mofaj/area/senkaku/index.html > 10:50 JST, $20 / 11 / 2019$ 
Which reconstruction is correct from the point of view of international jurisprudence and on the grounding of historical facts? Also, what were the implications of the so-called 'Tokyo Trial'? I shall try to explain this aspect at this juncture.

6. The idea of the illegality of the war, established in Asia at the Tokyo Trial, is a valid principle today. However, if Japan took possession of the Senkaku Islands by military force before the Second War, such an action would have been deemed legal according to the laws of the time and the Senkaku Islands would, even today, be considered an integral part of Japanese territory.

So why do China and the United States insist that the principle of the illegality of war was established before the Second World War? ONUMA Yasuaki, professor emeritus of the University of Tokyo, conducted studies on this discourse, and he arrived at important conclusions in the study he published in 19752. ONUMA concluded that the United States of America was attempting to justify its actions, despite the fact that the same US violated the international rules of neutrality in the Second World War.

After obtaining its independence from the United Kingdom, the US followed a policy of neutrality and concentrated all its energies on internal development. Therefore, as a non-aligned state, the US should have respected the rules of neutrality, which include the fundamental principle of treating all warring states equally. In opposition to its position, the US government decided to help the United Kingdom, its founding country, but it did so secretly because otherwise its actions would be construed as violating the rules of international law on neutrality. In this context, Nazi Germany fought against the United Kingdom and was defeated. The United Kingdom could not be conquered by Germany because of the covert help extended by the US. Nonetheless, the American media acknowledged the illegality of the US government's action. The American government tried to mask the illegitimacy of its actions in studies of international law and history because it wanted to avoid historical judgement on the wrongfulness of its actions. In short, the US government tried to disseminate the idea that war was forbidden as a state action under international law before the Second World War.

The American government tried to deny the right to war, but the rules of international law on neutrality were present in the system of international law on the very basis of the idea of war as a diplomatic and legal instrument. If the idea of the legality of the war was rejected, the rules of neutrality would have lost their validity and no one could have accused the US government of violating those rules.

Ultimately, Jackson, the representative of the US government, insisted at the so-called London Meeting for the application of the idea of the illegality of war at the Nuremberg International Military Court. Other states such as the United Kingdom, France and the Soviet Union accepted Jackson's insistence. This idea was transformed into a crime against peace during the Tokyo Trial. Further, the notion of the responsibility of the political leader was accepted and the Class A war criminal was born.

These two ideas about war, on which the American government insisted before the Tokyo Trial, have been recognised as principles of international law since the Second World War and they are valid today. The current system of international relations is essentially built on these ideas. These ideas and this interpretation of world history have been taught in US schools and universities as the official view of the American government.

2 ONUMA Yasuaki, Senso Sekinin-ron Josetsu, Univ., Press of University of Tokyo, 1975, (ISBN978-4-13-031085-7), pp. - . 
7. In legal science, we evaluate a case based on the laws that were in force at the time of the occurrence of the facts. Thus, we must find and determine the moment when the actualities in question occurred. In this case, there is no doubt about the timing of the incident; the dispute pertains to the interpretation of the law that is applicable to the parties involved. Both parties must share a fundamental and common conception about the law that prevails in human society or in a community. In other words, when there is a rule applicable to a case, a fundamental and common idea that is shared among the parties involved is implied.

8. So, is a common notion between Japan and China about the war that occurred between them before the Second World War? Evidently not.

Speaking of the differences between the two states' fundamental ideas about that war, Japan believes that war was deemed to be legal before and during the Second World War and that therefore, the right to self-defence could be applied in international relations issues pertaining to this period. Instead, China and the United States think that war was illegal even before the Second World War.

9. Can Japan continue today to support its version of the war against China by underscoring the opinion articulated by Judge Pal in the Tokyo Trial? A study conducted by an international relations researcher explains that there is a new cold war between China and the United States in East Asia and that North Korea is a factor of instability in this context.

This situation could push the United States to support Japan, but this eventuality seems impossible because if the US does so, it would have to admit its own falsification of history. Conversely, the US insists on supporting the Chinese interpretation it would embarrass Japan, which is now an allied nation. Thus, the US is trying to get the two states to solve the problem bilaterally, without involving itself in the controversy.

Japan would like to insist that the US supports the Japanese version of the notion of the war but cannot do so. Such an insistence would clash with US foreign and domestic policy. Therefore, Japan insists that it obtained the Senkaku Islands peacefully, based on historical evidence, regardless of whether the war is legal or illegal. China, on the other hand, maintains a version similar to the stated position of the United States. The visits of politicians to the Yasukuni Shrine and the reconstruction of history in Japanese textbooks are still criticised in South Korea. Needless to say, South Korea is positioned against Japan on this issue and supports the US-China version of the war.

In East Asia, therefore, every country, including the United States, espouses a different notion about the legality of war and no agreement can be reached on the law applicable to territorial problems. This controversy did not emerge until long after the Second World War.

10. In these last minutes, I would like to briefly present views on the Tokyo Trial. Japan and other states around the world accepted the idea of a US-backed war after the Second World War. In particular, the notion was accepted by Japan, which was never colonised and prospers today. The position was also supported by states around the world that were freed from colonial rule after the Second World War. This situation represents the effects or the fruits of the American idea. If Japan denies the American idea, how can today's Japanese state be conceived? There is a contradiction between the theory of legal science and 
the Japanese reality.

In this regard, I think that the understanding of the history of the world requires the recognition that the Tokyo Trial was revolutionary from a legal point of view. Usually, there is no precise or exact definition of what constitutes a revolution, so from the point of view of legal science, one can think of a revolution as a reform of the fundamentals of law and legal notions. The dominant states in the world did not change their positions on the occasion of the Tokyo Trial, but a profound reform of international law was instituted. If this reality is believed, there is no need to think of the historical facts in terms of a contradiction; the principle of non-retroactivity applies as indicated by Judge Pal, and we can consequently explain the current circumstances.

Another problem may be articulated: a cold war situation exists in East Asia and we face the danger of the eruption of war despite the affirmation of the currently accepted idea that war is illegal. Why does this danger exist in East Asia?

I think it is useful to cite TANAKA Akihiko ${ }^{3}$, a professor at the University of Tokyo, and Dr. Hedley Bull. They emphasise the importance of thought over time. Today, in 2014, all Asian states are supposed to follow the current ideas and principles of international law. In reality, however, some of the Asian states still reason on the basis of the principles of the old system that believed it was legitimate to use military power to resolve international disputes if necessary. I think the system of international law to which these states refer is the one before the Second World War. In the event of disputes that occur between a country that follows the current system and one that follows the pre-war system, it is not possible for the two states to agree on the action of one against another. For example, the European Union is made up of member states that can coordinate their actions, but East Asia is a region that houses many varying types of nations such as Japan which is modern in its outlook; China, a country that alludes to past systems; North Korea, whose actions are inexplicable; and also others. It follows that there are numerous eras and timelines for concerted international action to be taken.

In such circumstances, every Asian country chooses to evaluate its actions according to a system of international law in force at a particular point of time. When, for example, China uses military force, it claims that it is exercising legitimate self-defence to widen its influence and its territories in East Asia. In fact, Asians are moving away from the current international community's ideal of peaceful resolution.

11. In conclusion, China exerts immense influence on the Asian world, but its fundamental ideas are different from the Japanese beliefs since it inhabits a different period of time from the one in which the Japanese exist. For this reason, the territorial dispute between the two states cannot be resolved despite seventy years having already lapsed since the Second World War.

Ultimately, Asia is faced with the fundamental problem of how China may be ushered into the contemporary period.

Thank you for your attention.

3 TANAKA Akihiko, Atarashii Chusei, Nikkei Publishing Inc., 2003 (ISBN978-4-532-19173-3), 362p. 